\title{
The Influence of Temperature on the Properties of Gold Electrodeposits
}

\author{
J. W. Dini
}

Sandia Laboratories, Livermore, California

High temperature property data have been obtained for deposits from two different gold plating solutions, a citrate bath and a sulphite bath, while the influence of annealing at temperatures up to $500^{\circ} \mathrm{C}$ on the room temperature properties of the deposits has also been determined.

Relatively few data are available in the technical literature on the mechanical properties of gold deposits. This is particularly true for their properties at high temperatures. Since such information was needed at Sandia for comparing results of solid phase bonding work between electrodeposited gold and nickel with wrought gold and nickel, studies were undertaken on deposits from two different gold plating solutions.

Recently Cady and Willcox (1) published some pertinent information on gold deposits, and these data, together with some available on the elevated temperature strength of annealed gold wire $(2,3)$, serve as good bases for comparisons.

\section{Experimental Details}

Gold was electroformed in thicknesses ranging from 10 to 14 mils in two different plating solutions, based on citrate (4) and sulphite respectively (5). Operating conditions for the gold plating solutions
Table I

Operating Conditions for Gold Plating Solutions

\begin{tabular}{l|c|c} 
Solution & Citrate & Sulphite \\
\hline Reference & 4 & 5 \\
Tamperature ${ }^{\circ} \mathrm{C}$ & 60 & 49 \\
$\mathrm{pH}$ & 4.3 & 9.5 \\
$\begin{array}{c}\text { Current Density } \\
\left(\mathrm{A} / \mathrm{dm}^{2}\right)\end{array}$ & 0.32 & 0.32
\end{tabular}

are detailed in Table I. Mandrels were 3 by 6 by 0.062 inch aluminum panels and they were removed from the electroform by dissolving in caustic solution. A Mohler-Schaefer (6) box was used to ensure uniformity during deposition. Tensile specimens with a two-inch reduced section were machined,

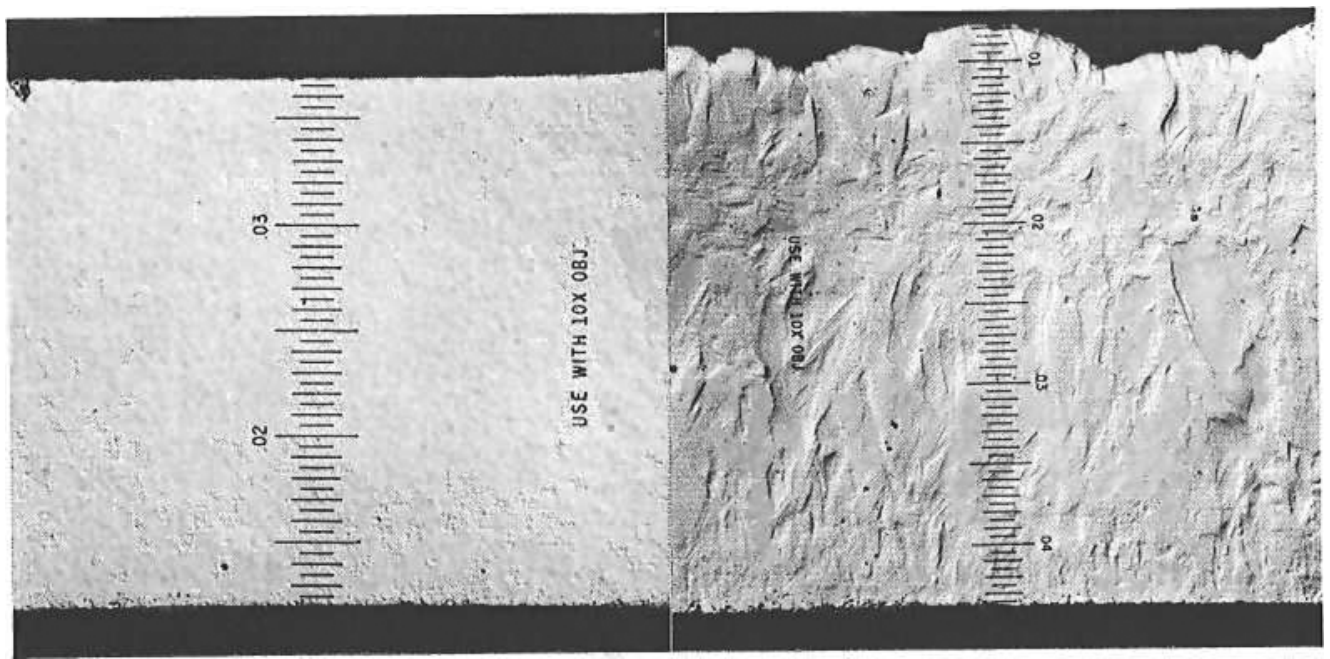

Fig. 1. Cross section of a sulphite deposit showing the extremely fine grained structure typically obtained. This deposit was produced at a current density of $0.32 \mathrm{~A} / \mathrm{dm}^{2}$, a pH of 9.5 , and a temperature of $40^{\circ} \mathrm{C}$
Fig. 2. Cross section of a citrate deposit consisting chiefly of relatively large, columnar grains. This deposit was produced at a current density of $0.32 \mathrm{~A} / \mathrm{dm}^{2}$, a $\mathrm{pH}$ of 4.3 , and a temperature of $60^{\circ} \mathrm{C}$ 
using a Tensilkut template, and were then tested on an Instron machine.

Some specimens were tested after holding at 200 and $260^{\circ} \mathrm{C}$ for 20 minutes in an Instron temperature chamber. Time to reach temperature was approximately one hour. Others were heated at temperatures ranging from 100 to $500^{\circ} \mathrm{C}$ prior to testing at room temperature.

Representative samples of each deposit were cross-sectioned and mounted in plastic for metallographic inspection and for the determination of hardness. In addition, the impurities in the deposits were determined by emission spectrographic analysis.

\section{Results}

The sulphite deposits were stronger than the citrate deposits and retained higher strengths throughout the tests. This is most probably due to the extremely fine grained structure of these deposits, as shown in Figure 1. Craig et al. (7) reported that surfaces from this solution were completely featureless even when viewed at 30,000 magnification with a scanning electron microscope. The citrate deposit, on the other hand, consisted of relatively large, columnar grains as shown in the photomicrograph of Figure 2.

Data for specimens of both types of deposits tested at 200 and $260^{\circ} \mathrm{C}$ showed a steady drop in tensile strength as a function of testing temperature the results are set out in Table II. At $200^{\circ} \mathrm{C}$ the strength of the citrate deposit agreed quite well with that for annealed gold wire, while the sulphite deposit was slightly stronger. Increasing the testing temperature to $260^{\circ} \mathrm{C}$ reduced the strength of the citrate deposit to slightly less than that for gold wire, whereas the sulphite deposit remained slightly stronger than gold wire.
Tensile and yield properties of annealed citrate deposits showed slight reductions starting around $300^{\circ} \mathrm{C}$ and then larger reductions at higher temperatures. Elongation dropped immediately as a result of heating and then remained essentially constant for the entire temperature range evaluated. The results are given in Table III, which also includes for comparison the data of Cady and Willcox (1), which show some noticeable differences in every column.

This was undoubtedly due to the fact that they were using quite thin deposits $(0.7$ to $1.0 \mathrm{mil})$ compared with those used at Sandia (10 to 14 mils). Improvements they obtained as a result of heating simply brought their elongation values in line with those obtained at Sandia.

Comparison of these two sets of data clearly shows the influence of thickness on properties of deposits. Cady and Willcox (1) discussed this phenomenon for unannealed gold deposits, while others have reported similar relationships for nickel (8) and copper (9).

The sulphite deposits also showed a reduction in yield and tensile strength as a function of temperature, but elongation improved considerably with temperature.

Hardness of the citrate deposit was 60 Knoop (25 gram load) and $58 \mathrm{Knoop}$ after heating at $500^{\circ} \mathrm{C}$ for one hour. The sulphite deposit gave a figure of 96 Knoop in the as-plated condition and $82 \mathrm{Knoop}$ after the $500^{\circ} \mathrm{C}$ heat treatment.

Emission spectrographic analysis of the deposits revealed that those produced in the citrate solution were quite pure; no individual contaminant was present in quantities greater than 10 p.p.m. The sulphite bath, however, was found to contain noticeable amounts of lead ( $<1000$ p.p.m.), arsenic $(<100$ p.p.m.) and tin $(<100$ p.p.m.).

Table II

Tensile Strength of Gold Deposits and Gold Wire at High Temperature

\begin{tabular}{|c|c|c|c|c|c|}
\hline \multirow[b]{2}{*}{ Testing } & \multirow[b]{2}{*}{$\underset{{ }^{\circ} \mathrm{C}}{\text { Temperature }}$} & \multicolumn{2}{|c|}{ Gold Wire } & \multicolumn{2}{|c|}{$\begin{array}{c}\text { Gold Deposits } \\
\text { Tensile Strength (p.s.i.)* }\end{array}$} \\
\hline & & $\begin{array}{l}\text { Poniatowski and } \\
\text { Clasing }\end{array}$ & Reinacher & Citrate & Sulphite \\
\hline & 17 & 18,900 & 19,100 & 18,300 & 26,500 \\
\hline & 200 & 15,600 & 15,600 & 15,900 & 17,300 \\
\hline & 260 & 14,200 & - & 12,100 & 15,800 \\
\hline & 400 & 11,800 & 12,800 & - & 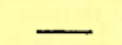 \\
\hline
\end{tabular}

*Specimens were tested in an Instron temperature chamber at a crosshead speed of $0.050 \mathrm{inch} / \mathrm{min}$. One hour was allowed to reach testing temperature; specimens were then held at temperature for 20 minutes before testing. 
Table III

Properties of Annealed Gold Deposits

\begin{tabular}{|c|c|c|c|c|c|}
\hline $\begin{array}{l}\text { Plating Solution } \\
\text { and Current Density }\end{array}$ & $\begin{array}{l}\text { Thickness of } \\
\text { Deposit } \\
\text { (mils) }\end{array}$ & $\begin{array}{c}\text { Annealing } \\
\text { Temperature } \\
\left({ }^{\circ} \mathrm{C}\right)^{*}\end{array}$ & $\begin{array}{l}\text { Yield } \\
\text { Strength } \\
\text { (p.s.i.) }\end{array}$ & $\begin{array}{l}\text { Tensile } \\
\text { Strength } \\
\text { (p.s.i.) }\end{array}$ & $\begin{array}{c}\text { Elongation } \\
\text { (\% in } 1.0 \text { in) }\end{array}$ \\
\hline Acid citrate, & 10 & - & 11,000 & 18,300 & 19.4 \\
\hline \multirow[t]{5}{*}{$0.32 \mathrm{~A} / \mathrm{dm}^{2}$} & & 100 & 11,400 & 18,500 & 12.9 \\
\hline & & 200 & 11,600 & 18,800 & 12.5 \\
\hline & & 300 & 11,400 & 17,400 & 14.5 \\
\hline & & 400 & 9,300 & 16,900 & 12.8 \\
\hline & & 500 & 4,800 & 14,200 & 13.6 \\
\hline Sulphite, & 14 & - & 23,800 & 26,500 & 5.8 \\
\hline \multirow[t]{2}{*}{$0.32 \mathrm{~A} / \mathrm{dm}^{2}$} & & 100 & 22,900 & 25,900 & $\mathrm{~B} * *$ \\
\hline & & 200 & 22,200 & 24,200 & $\mathrm{~B} * *$ \\
\hline \multirow[t]{3}{*}{ mists } & & 300 & 21,800 & 24,300 & $B * *$ \\
\hline & & 400 & 19,700 & 21,600 & $\mathrm{~B} * *$ \\
\hline & & 500 & 12,800 & 14,300 & 20.0 \\
\hline & & & & & \\
\hline Acid citrate, & $0.7-1.0$ & - & 12,900 & 20,500 & $\begin{array}{r}5.0 \\
10.6\end{array}$ \\
\hline $0.11 \mathrm{~A} / \mathrm{dm}^{2}$ & & 200 & 4,600 & $\begin{array}{l}14,600 \\
15300\end{array}$ & $\begin{array}{l}10.6 \\
170\end{array}$ \\
\hline (Cady and Willcox) & & 300 & 3,600 & 15,300 & 17.0 \\
\hline Acid citrate, & $0.7-1.0$ & - & 20,100 & 31,500 & 3.8 \\
\hline $0.54 \mathrm{~A} / \mathrm{dm}^{2}$ & & 100 & 19,700 & 31,700 & 3.6 \\
\hline \multirow[t]{2}{*}{ (Cady and Willcox) } & & 200 & 9,000 & 19,200 & 9.2 \\
\hline & & 300 & 8,100 & 18,700 & 16.1 \\
\hline
\end{tabular}

*Specimens were heated at temperature for 1 hour, prior to testing at room temperature.

**Specimens broke outside the gauge marks.

\section{Summary}

The high temperature properties of two different gold deposits were quite similar to those reported by other workers for annealed gold wire.

Annealing of sulphite-type gold deposits was found to cause a reduction in tensile and yield strength and an improvement in elongation. Citrate-type deposits also showed a reduction in both tensile and yield strengths.

Elongation values for these deposits dropped slightly as a result of heating.

Substantial differences were shown to exist between the data for citrate deposits and the results of other researchers who worked with much thinner specimens, and it is considered that this work shows the importance of specifying thickness of deposits when reporting properties.

\section{Acknowledgments}

The author acknowledges with thanks the assistance given by his colleagues, including $H$. C. Feemster for analytical work, T. L. Bryant for metallographic support, W. R. Will for testing and J. R. Helms for plating assistance. S. D. Holmes of Sandia Laboratories, Albuquerque also provided assistance in the plating operations.

\section{References}

1 J. R. Cady and P. S. Willcox, Plating, 1973, 60, 139

2 M. Poniatowski and M. Clasing, Gold Bull., 1972, 5, 34

3 G. Reinacher, Metall, 1956, 13-14, 587

4 R. Duva and D. G. Foulke, U.S. Patent $3,156,634$

5 P. T. Smith, U.S. Patent 3,666,640

6 J. B. Mohler and R. A. Schaefer, Monthly Review of the American Electroplaters' Society, 1947, 34, 1361

7 S. E. Craig, Jr., R. E. Harr, J. Henry and P. Turner, F. Electrochem. Soc., 1970, 117, 1450

8 V. Zentner, A. Brenner and C. W. Jennings, Plating, $1952,39,865$

9 V. A. Lamb, C. E. Johnson and D. R. Valentine, $\mathcal{F}$. Electrochem. Soc., 1970, 117, (9), 281C-318C; (10), $341 \mathrm{C}-352 \mathrm{C} ;(11), 381 \mathrm{C}-404 \mathrm{C}$ 